\title{
The endemic vascular flora of Sardinia: a dynamic checklist with an overview of biogeography and conservation status
}

\author{
Mauro Fois ${ }^{1}$, Emmanuele Farris ${ }^{2,}$, Giacomo Calvia ${ }^{1}$, Giuliano Campus ${ }^{3}$, Giuseppe Fenu ${ }^{1}$, Marco Porceddu ${ }^{1,4}$ and \\ Gianluigi Bacchetta ${ }^{1,4}$
}

1 Centre for the Conservation of Biodiversity (CCB), Life and Environmental Sciences Department, University of Cagliari, Viale S. Ignazio da Laconi 11-13, 09123 Cagliari, Italy; mfois@unica.it (M.F.); giacomo.calvia@gmail.com (G.C.); gfenu@unica.it (G.F.); bacchet@unica.it (G.B.)

2 Department of Chemistry and Farmacy, University of Sassari, Via Piandanna 4, 07100 Sassari, Italy; emfa@uniss.it

3 Independent researcher, Via G. Rossini 69, 09045 Quartu Sant'Elena (CA), Italy; 54.campus@libero.it

4 Sardinian Germplasm Bank (BG-SAR), Hortus Botanicus Karalitanus (HBK), University of Cagliari, Viale S. Ignazio da Laconi, 9-11, 09123 Cagliari, Italy; porceddu.marco@unica.it (M.P.)

* Correspondence: emfa@uniss.it; Tel.: +39 079228675

\begin{abstract}
The vascular flora of Sardinia has been investigated for more than 250 years, with particular attention to the endemic component, due to their phylogeographic and conservation interest. However, continuous changes in the floristic composition through natural processes, anthropogenic drivers or modified taxonomical attributions require constant updating. We checked all available literature, web sources, field and unpublished data from authors and acknowledged external experts to compile an updated checklist of vascular plants endemic to Sardinia. Life and chorological forms, and the conservation status of the updated taxa list were reported. Sardinia hosts 340 taxa ( $15 \%$ of the total native flora) endemic to the Tyrrhenian islands and other limited continental territories; 195 of these are exclusive to Sardinia. Asteraceae (50 taxa) and Plumbaginaceae (42 taxa) are the most representative families, while the most frequent life forms are hemicryptophytes (118 taxa) and chamaephytes (105 taxa). The global conservation status, available for 200 taxa, indicates that most endemics are under the 'Critically Endangered' (25 taxa), 'Endangered' (31 taxa) or 'Least Concern' (90 taxa) IUCN categories. This research provides an updated basis for future biosystematics, taxonomic, biogeographical and ecological studies, and for supporting more integrated and efficient policy tools.
\end{abstract}

Keywords: Mediterranean flora; endemic plants; IUCN assessments; island biogeography; plant conservation; Tyrrhenian islands; biological forms; plant evolution and distribution; plant diversity

\section{Introduction}

The concept of 'endemism' is apparently simple but actually problematic [1]. Previous studies on Mediterranean endemic vascular plants led to two main approaches for defining this concept. A first approach attempted to give weight to the time of origin of a given endemic taxon [2,3]. On this basis, palaeoendemic (systematically isolated species), schizoendemic (phenotypically and karyologically similar species originated by allopatric speciation from a widespread ancestor) and neoendemic (recently diversified species or still diversifying lineages) taxa were defined. However, there is lack of phylogenetic and phylogeographic studies for many taxa, and thus the feasibility of this approach is far from being achieved, despite the increasing number of recent scientific papers are shedding light on this crucial aspect [e.g., 4-8]. The first attempt to organically describe the endemic vascular flora of Sardinia (consisting in the presentation of 202 taxa on the Bulletin of the Sardinian Society of Natural Sciences by Arrigoni et al. [9]) was based on this first approach. Although a valid milestone for the taxonomic, nomenclatural, ecological 
and geographical description of a huge contingent of endemic taxa, the work of Arrigoni et al. [9] did not produce a satisfactory and coherent synthesis [10]. The main reason was that it was based on some merely speculative assumptions.

More recently, a second approach has prevailed, based on the current distribution range of a given taxon, regardless of its age [11,12]. This concept is often used to define taxa whose geographic range is markedly more restricted than the average distribution of systematically comparable taxa. The definition is therefore inherently relative because the scale at which a taxon is restricted has to be defined subjectively [e.g., 2,12-14]. According to this approach, Thompson [12] recognised four categories: narrow, disjunct, regional, and Mediterranean endemic plants.

The categories originated by the two approaches are neither comparable nor overlapping. For instance, a narrow endemic plant could be either a palaeoendemic (e.g., Ribes sardoum), a schizoendemic (e.g., Silene ichnusae) or a neoendemic (e.g., Anchusa sardoa) [1517]. In summary, the concept of endemism more used at present (and adopted in this paper), is a function of the spatial scale used to describe the restriction of the distribution of certain taxa to a definite sized area [18]. To which territory a taxon is endemic may be defined according to the specific study aim. For instance, a checklist of plants endemic to a country or a region can be useful for policy [e.g., 19,20], while, for pure-scientific purposes an endemic flora is usually defined on a biogeographical basis $[11,21]$. In both cases, richness of endemic taxa in a region is one of the fundamental features of biodiversity and is valuable in the context of nature conservation policies [22]. Assessing the conservation status and the need for management actions of endemic plants is therefore of utmost importance while allocating limited financial resources $[11,19,23]$.

Tyrrhenian continental islands in the central-western Mediterranean (Corsica, Sardinia, Balearic, Tuscan Archipelagoes and Sicily) constitute one macro-hotspot of plant diversity within the Mediterranean mega-hotspot [23]. They are recognised as glacial refugia [24] and are both a reservoir of genetic diversity for widespread Mediterranean plants [25,26] and a centre of conservation and differentiation of endemism [8,27]. Sardinia is considered a meso-hotspot within the Tyrrhenian Islands macro-hotspot of biodiversity [23], with rates of endemism ranging between $13 \%$ and $15 \%$ of the local flora $[12,23,28]$. For its palaeogeography, current high geological and geomorphological diversity and degree of isolation, the island supports several ancient or relict (i.e., palaeoendemics) and recently differentiated endemic plants (i.e., neoendemics) $[19,29,30]$. The reported numbers of the vascular plants endemic to Sardinia vary according to the reference spatial extent and recent discoveries or taxonomic reviews. Considering only data reported during the current century, 347 taxa (including hybrids and varieties) were included in the checklist by Bacchetta et al. [31] as endemics to Sardinia and shared with Tyrrhenian islands. The exclusive component of the island was assessed by Bacchetta et al. [19] at 168 taxa, 139 of which were species, 23 subspecies, 4 varieties and 2 hybrids. These numbers slightly increased according to more recent updates in Cañadas et al. [23] and in Fenu et al. [29] with 171 exclusive taxa. With a different approach, related to the political boundaries, Peruzzi et al. [20] recorded 180 'strict regional endemic' and 322 'Italian endemic' vascular plants for Sardinia.

Sardinia hosts around $25 \%$ of the 932 taxa native to Italy that were assigned to a risk category, mostly due to human disturbance [32,33]; of these taxa, 99 are endemic to the island. However, other studies accounted for further specific demographic, ecological and environmental causes of extinction risks, such as in the case of the endemic taxa belonging to the genera Anchusa [16,34], Astragalus [35] and Centaurea [36,37] or in the case of specific environments, such as wet habitats [38], pastures [39], coastal sand dunes [40,41] and small satellite islets [42,43]. Of the 21 vascular plants currently known in Sardinia and listed in the Annex II of the Habitats Directive (43/92/EEC), 17 are endemic [44]. Furthermore, five exclusive endemics (Aquilegia barbaricina, A. nuragica, Lamyropsis microcephala, Polygala sinisica and Ribes sardoum), were included by the IUCN/SSC - Mediterranean Plant Specialist Group in the 'Top 50 Mediterranean Island Plants' to be urgently conserved [45]. 
In this study, we present a checklist of vascular plant taxa endemic to Sardinia. Starting from the literature and unpublished knowledge by several field surveys and suggestions of the authors and external experts, a dynamic checklist was critically defined and discussed. The main aims of this study were: (1) to present and discuss an updated critical checklist of the vascular plants endemic to Sardinia; (2) to interpret their biogeography and distribution patterns; (3) to summarise their currently known conservation status; (4) to highlight and discuss gaps and future directions for their knowledge and conservation improvement.

\section{Results}

The checklist of vascular plants endemic to Sardinia includes 340 taxa, of which 275 are includenda and 66 inquirenda (see 'Criteria for the selection of endemic taxa' in the Materials and Methods section); further 15 taxa have been excluded (i.e., taxa excludenda). The 340 endemic taxa, representing around $15 \%$ of the native Sardinian vascular flora, are referred to 52 families, representing $42 \%$ of the 125 families of the native Sardinian flora. There are some similarities between the dominant endemic and native families in Sardinia: in both cases, the most represented family is Asteraceae, with 248 native and 49 endemic taxa. Plumbaginaceae is one of the most important exceptions, being the second largest family in endemic taxa, with $75 \%$ of native taxa being endemic. On the other side, Poaceae, which is the third most representative family in the total native flora (211 taxa), is only the ninth family in endemics, with just 12 taxa, equal to $6 \%$ of total native Poaceae of Sardinia (Table 1).

Table 1. Number of endemic vascular taxa (and their relative percentage of the total taxa of the native flora) of the ten richest families in endemic species. The two most speciesrich endemic genera and their respective number of doubtful taxa (i.e., inquirenda) is also reported for each family.

\begin{tabular}{llll}
\hline Family & no. taxa & no. inquirenda & Most representative genera (no. taxa) \\
\hline Asteraceae & $49(20 \%)$ & 17 & Hieracium (7), Taraxacum (6) \\
Plumbaginaceae & $42(75 \%)$ & 12 & Limonium (38), Armeria (4) \\
Fabaceae & $27(12 \%)$ & 0 & Genista (18), Astragalus (7) \\
Caryophyllaceae & $26(21 \%)$ & 0 & Silene (9), Dianthus (9) \\
Lamiaceae & $16(22 \%)$ & 3 & Stachys (3), Micromeria (2), Mentha (2), Teucrium (2) \\
Boraginaceae & $13(28 \%)$ & 0 & Anchusa (7), Borago (2) \\
Orchidaceae & $13(20 \%)$ & 5 & Ophrys (9), Orchis (2), Serapias (2) \\
Apiaceae & $12(13 \%)$ & 2 & Seseli (2), Siler (2) \\
Poaceae & $12(6 \%)$ & 2 & Sesleria (3), Festuca (2), Trisetaria (2) \\
Ranunculaceae & $12(19 \%)$ & 1 & Ranunculus (5), Aquilegia (4) \\
\hline
\end{tabular}

The life form analysis highlighted a clear predominance of hemicryptophytes (117 taxa) and chamaephytes (107), followed by geophytes (55), phanerophytes (29 nano-phanerophytes + six phanerophytes) and therophytes (26). The majority of taxa are endemic exclusively to Sardinia (194 taxa); further 81 taxa are endemic to Sardinia and Corsica, together accounting for $81 \%$ of the total endemic vascular flora (Fig. 1). 


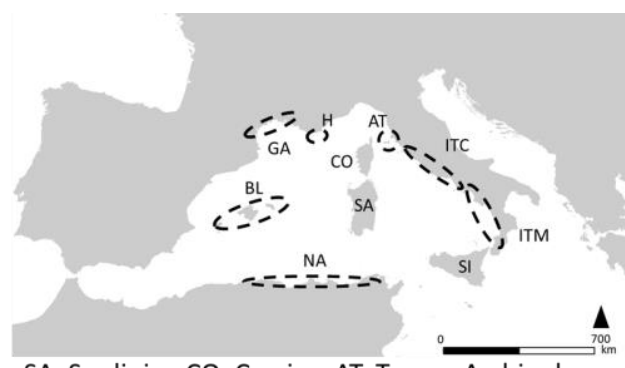

SA: Sardinia; CO: Corsica; AT: Tuscan Archipelago; SI: Sicily; BL: Balearic Archipelago; ITM: Southern Italy; ITC: Central Italy; NA: Northern Africa; GA: S France \& NE Spain; $\mathrm{H}$ : Hyères Islands

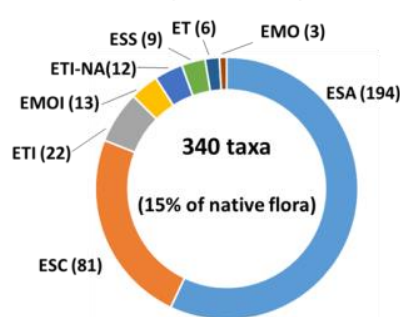

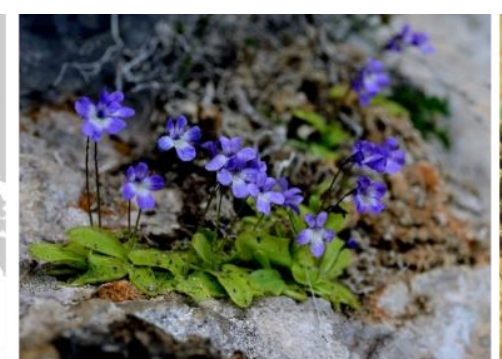

Pinguicula sehuensis (ESA)

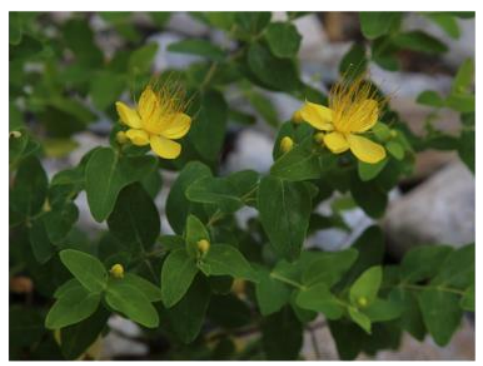

Hypericum hircinum subsp. hircinum (ETI)

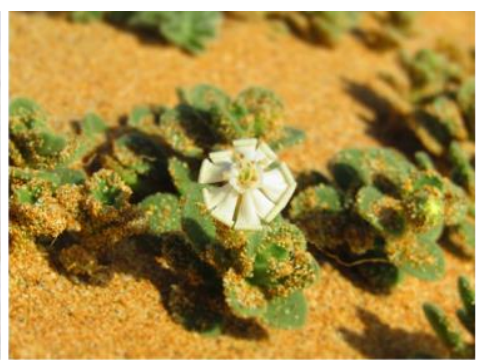

Silene succulenta subsp. corsica (ESC)

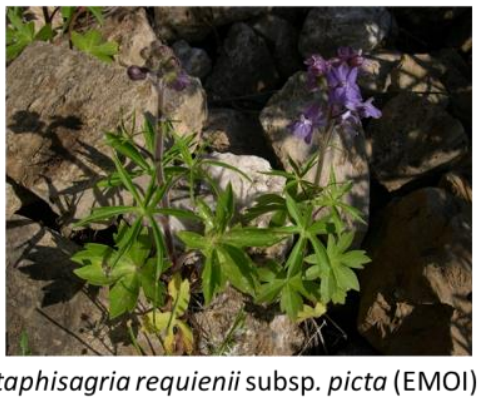

Figure 1. Chorological spectrum of the Sardinian endemic flora. On the right, taxa representative to the four main chorological categories: ESA (SA), ESC (SA+CO), ETI (SA $\pm \mathrm{CO}+\mathrm{AT}$ and/or SI), EMOI $(\mathrm{SA} \pm \mathrm{CO} \pm \mathrm{AT}+\mathrm{BL}$ and/or $\mathrm{H}), \mathrm{ESS}(\mathrm{SA}+\mathrm{SI}), \mathrm{ETI}-\mathrm{NA}(\mathrm{ETI}+\mathrm{NA}), \mathrm{ET}(\mathrm{SA}+\mathrm{ITM}$ or ITC), EMO (SA+CO and/or GA, ITM, ITC).

Our dataset included the global assessment of the extinction risk for 200 taxa, $82 \%$ of which are exclusive to Sardinia. The remaining 140 endemic taxa were assessed as 'Data Deficient' (DD; 14 taxa) or 'Not (yet) Evaluated' (NE; 126 taxa); $63 \%$ of inquirenda are under these two last categories. A total of 90 taxa (equal to $26 \%$ of the total vascular endemic flora) are of minor or 'Least Concern' (LC). The downside is that $21 \%$ of the 340 endemics are Vulnerable (VU, 16 taxa), Endangered (EN, 31 taxa) or Critically Endangered (CR, 25 taxa). Among the most common families, Plumbaginaceae were generally less threatened than average (64\% of them are LC), while worth of special attention are likely the Boraginaceae (38\% of them under EN or CR categories), Fabaceae (29\% of them under EN or CR categories) and Ranunculaceae, with $23 \%$ of endemic taxa CR and $50 \%$ not yet evaluated (NE). The Apiaceae (66\%), Lamiaceae (62\%) and Orchidaceae $(61 \%)$ resulted the families with the highest percentages of taxa under the DD and NE categories (Fig. 2). 


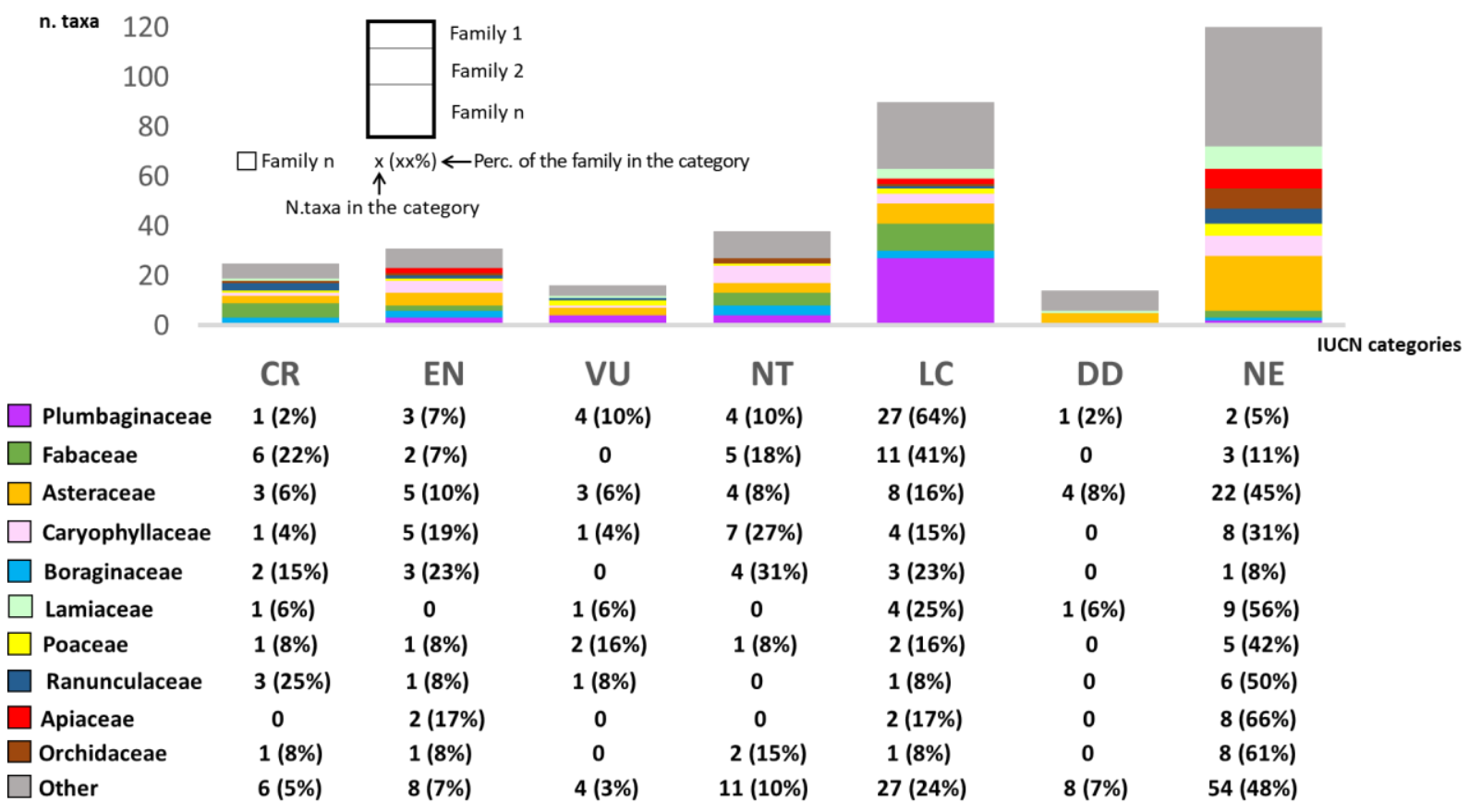

Figure 2. Numbers of vascular plant taxa distributed in the IUCN Red List categories, by family. Only the most numerous families in each category were plotted. CR: Critically endangered, EN: Endangered, NT: Near Threatened, LC: Least Concern, DD: Data Deficient, NE: Not Evaluated.

\section{Discussion}

The flora of Sardinia has been subject to botanical studies for more than 250 years, starting from the first flora published by Allioni [46], to those of Moris [47], Barbey [48], Martelli [49,50], Terracciano [51-53], and up to the recent contribution of Arrigoni [54]. In contrast to the whole flora, the endemic contingent received relatively recent specific attention, with a first attempt to achieve a comprehensive survey and synthesis less than 50 years ago [9]. After several proposals for a modern synthesis of the Sardinian endemic vascular flora [11,19,31], this research updates the 30-year-old list of Sardinian endemic vascular plants [9], incorporating updates of recent findings, new taxa descriptions and considering recent taxonomic revisions. Including all taxa shared with other Tyrrhenian islands and limited portions of palaeogeographically affine continental territories, it represents the first synthesis of the entire Sardinian endemic component. Another relatively uncommon approach is to present a 'dynamic' checklist, which is conceived to be constantly under review and in progress. All the taxa listed here, but especially those included under the doubtful status (i.e., inquirenda), are therefore taxa that will most likely be amended and adapted in the future in the light of expected scientific advances and discoveries. This approach has been already adopted for other recent floras [e.g., 55,56] to broaden the debate and highlight the need of further research in even so relatively studied territories. Among others, many inquirenda are those cryptic and doubtful taxa belonging to the genera Limonium, Ophrys and several Asteraceae - especially those from the Cichorieae tribe - such as the ones of the genera Hieracium and Taraxacum. All these groups were already outlined as problematic, due to their phylogenetic complexity and instability [e.g., 57-59]. As elsewhere in the world [60], most taxa, even several includenda, were described on the basis of morphological characters and then never confirmed by molecular evidence.

\subsection{Quantitative features}


Overall, our checklist accounts for 340 includenda and inquirenda, which are representing around $15 \%$ of the Sardinian vascular native flora known to date (ca. 2,300 taxa). Further 16 taxa were retained in a second list of excludenda, due to the absence of recent evidence of their presence in Sardinia or taxonomic validity. However, we left a trace of their mention within the Sardinian endemic component in order to encourage possible future investigation and re-evaluation. Even though numerical comparisons with other islands are difficult, for the above-mentioned subjectivity in the definition of the endemic component, the high phytogeographic interest of the Sardinian flora is confirmed here. Moreover, geographical biases in species discovery and descriptions have been often found [e.g., $61,62]$ and should always be considered when discussing quantitative features of species checklists. Our results are in accordance with those recently published by Thompson [12] and Médail [28], who reported similar percentages of endemic vascular plants of Sardinia. Furthermore, it is noteworthy that the percentages of endemic vascular plants exhibited by Sardinia are similar or even slightly higher than those of the rest of Mediterranean large islands (see summary presented in Médail [63] and comparable to those showed by some tropical continental islands such as the large island of Hainan, with a size similar to Sardinia $\left(33,210 \mathrm{~km}^{2}\right.$ [64]), or many small oceanic islands of Eastern Polynesia [65]. All these comparative data sustain the inclusion of Sardinia and the other Tyrrhenian islands within the "hottest" global hotspots of plant biodiversity, as already underlined by several authors $[12,23,28,63,66,67]$.

\subsection{Taxonomical analysis}

As in other island floras of the western Mediterranean, Asteraceae is the most represented family with 49 endemic taxa (14\% of the Sardinian endemic flora): this family accounts for $25 \%$ of the Corsican endemic flora, $22 \%$ in that of Sicily and $13 \%$ in the Balearic Islands endemic flora [68-70]. The other families (Plumbaginaceae, Fabaceae and Caryophyllaceae), which are dominant in the Sardinian endemic flora, are also well represented in most of the other western Mediterranean islands. Within the Asteraceae, apart from the absence from the near Corsica of the well represented and still diversifying genus Centaurea, already underlined by other authors [8], here is worth of mention the fact that, amongst Cichorioideae, in Sardinia there are some shrubby taxa (notably Plagius flosculosus and Buphthalmum inuloides), whereas woody Cichorioideae seem absent from other Mediterranean islands and are otherwise well represented in Macaronesia [71].

The preponderance of species belonging to the family Plumbaginaceae is mainly due to the 38 taxa of the genus Limonium [57], which has a centre of diversification in the Mediterranean Basin (around 90\% of European taxa are concentrated here). This genus comprises sexual and apomictic perennial herbs and sub-shrubs referring to the complex of species that evolved in the proto-Mediterranean area from some diploid species living on inner rocks or sea cliffs during the Oligocene and subsequently extensively diversified during the Messinian salinity crisis and Plio-Pleistocene sea-level fluctuations [72,73]. Regarding this family, it should be noted that the second genus with endemic taxa (Armeria) is present in all large western Mediterranean islands, but not in the Balearic Archipelago.

Regarding the third largest family of the Sardinian endemic flora, Fabaceae, which is underrepresented in the Corsican endemic flora [70], Tyrrhenian islands represent a speciation centre for many plant groups associated with Tertiary floras, such as the Genista ephedroides and G. salzmannii groups [74,75]. This explains the presence of 16 Genista taxa exclusive to Sardinia.

The same is true for some genera of the fourth family, Caryophyllaceae, being Sardinia also a centre of diversification of the Dianthus sylvestris group, nine taxa of which are exclusive to the island. The taxa belonging to this group mainly occur in rupestrian habitats, on rocky and sandy grasslands, garigues, and mesic meadows; several of them are affine to Sicilian endemic taxa belonging to the same genus [76]. Even though the evolutionary processes within the group are still debated [77], these were also probably forced by the Messinian salinity crisis and by their characteristic inbreeding depression syndrome and unusual summer-flowering phenology [78,79]. Similar hypotheses were made 
for some of the rest of Caryophyllaceae, such as taxa belonging to the Silene mollissima aggregate $[80,81]$.

Worth of mention is also the high endemism rate among the Boraginaceae family, especially due to the genus Anchusa, a moderate-sized genus with seven allopatric endemic taxa - out of a total of about 30 taxa of the entire genus - living in either coastal or mountain habitats of the island and having a probable common genetic pool of tertiary origin $[5,16,82,83]$. The high number of endemic taxa belonging to the family Boraginaceae is, especially if considering the genus Anchusa, exceptional with respect to the rest of western Mediterranean insular territories and comparable only to the number of endemic Echium in the Canarian Archipelago, with which Sardinia shares a Boraginaceae ancestor of Anatolian origin [5].

Although Sardinia does not host any endemic family, unlike many large oceanic and continental tropical islands (for example, Madagascar alone includes five endemic families and 321 endemic genera, see Callmander et al. [84]), the biogeographical originality of the Sardinian flora is underlined by the presence of three exclusive genera (Castroviejoa, Morisia and Nananthea), and one subgenus (Buglossites, within the genus Borago), all shared with the neighboring Corsica: this sharing reinforces the vision of a unique Cyrno-Sardinian biogeographical province including the Tuscan Archipelago [19,29], where the subgenus Buglossites is also present [82]. The original character of the Sardinian endemic flora, compared to that of Corsica and the other large western Mediterranean islands and mainland territories, is emphasised by some very geographically and/or taxonomically isolated species, survived (or differentiated) only in Sardinia such as Lamyropsis microcephala [85] and Ribes sardoum [86].

Few coastal endemics, mainly in the archipelagos of La Maddalena and Tavolara, are exclusive to the offshore satellite islands $[87,88]$. Most of them are instead shared with the coastal areas of the main Sardinian island, to which were connected during the last PlioPleistocene eustatic fluctuations. However, these islands and islets, mostly uninhabited, act as modern refugia from the human and herbivory-related pressures [42].

\subsection{Life forms}

Considering Raunkiaer's life forms, the endemic flora is quite different from the whole Sardinian flora, being therophytes the dominant biological type in the whole flora but the less represented in the endemic one. The low incidence of endemic therophytes is influenced by their very effective dispersal strategies [89]. Moreover, therophytes are less common in highly selective habitats and at higher elevations, where endemic taxa are most frequent [90]. As in the endemic flora of Corsica [70], hemicryptophytes are the dominant biological type. The ratio between chamaephytes and hemicryptophytes is almost equal to one in Sardinia, while in Corsica hemicryptophytes prevail considerably. This difference between Sardinian and Corsican components could be conditioned by different present and past climatic conditions. For both islands, high percentages of chamaephytes and hemicryptophytes confirm the crucial role of the ecological insularity of mountain massifs for the differentiation of the endemic flora $[19,23,30]$. In particular, the antiquity of Sardinian mountains and the high incidence of limestone cliffs, have promoted the persistence of relict palaeoendemic taxa as well as more recent allopatric evolutionary processes that have given rise to many specialised chasmophytes [e.g., 88,91-93]. Chamaephytic and hemicryptophytic forms are also particularly adapted to the severe wind, salt spray and aridity that are typical of coastal environments [e.g., 94-96] around the about $1900 \mathrm{~km}$ of coastline, characterised by a variety of landforms, such as cliffs, sandy dunes, long and pocket beaches, and by ca. 400 offshore satellite islands and small islets $[42,43,97]$, also considered as important local centres of endemism (i.e., micro- and nanohotspots sensu Fenu et al. [98], Cañadas et al. [23]).

Interestingly, Sardinia has more than $10 \%$ of phanerophytes (nano-phanerophytes included) in the endemic flora (whereas Corsica has less than 5\%), with 35 taxa belonging to genera Hypericum, Quercus, Rhamnus, Ribes, Rubus, Salix and especially Genista (18 en- 
demic taxa, Bacchetta et al. [74,75]). Higher levels of endemic phanerophytes than Sardinian endemic flora are in Sicily, the Balearic Archipelago and Cyprus, while lower percentages characterise the floras of Corsica, Greece, southern Spain and the Alps [68,70].

Spiny plants are also over-represented among Sardinian endemics with respect to the native flora. Other forms of adaptation to millennia of grazing/browsing pressures, such as the geophytic life form, the facilitative mechanisms among plants, or their toxicity are also common [e.g., 99-101]. These forms of adaptation are in fact common in the most represented families, such as Asteraceae, Fabaceae, Lamiaceae and Orchidaceae.

\subsection{Chorological types}

The largest portion of the endemic flora is composed of exclusive taxa (SA; 57\%), which, together with the taxa shared with Corsica (SA-CO; $24 \%$ ), represent ca. $81 \%$ of all endemics. The exclusive Sardinian taxa amount to $8.4 \%$ of the total Sardinian flora. Compared with other islands, this percentage of exclusive taxa is lower than in Sicily (10\%, Brullo et al. [68]), but higher than in Corsica (5.5\%, Jeanmonod et al. [70]). The high percentage of SA and SA-CO taxa provides further evidence for the floristic autonomy of the Cyrno-Sardinian flora, mainly due to its geographical and ecological isolation that favoured the in situ speciation of several taxa [4,66,70]. Interestingly, Sardinia has more exclusive endemic plants than Corsica (57\% Sardinia vs. $43 \%$ Corsica), whereas Corsica has much more endemic species shared with the mainland (17.7\% Corsica vs. $2.6 \%$ Sardinia) [70]. The latter difference suggests that, even if the two islands share a common floristic ancestry SA-CO taxa, accounting for $24 \%$ and $26 \%$ of the Sardinian and Corsican endemic flora, respectively, local differentiation of genetic lineages and isolation of narrow endemic species acted more in Sardinia than in Corsica. Moreover, Corsica maintained more contacts with continental land masses, is smaller in extension and less surrounded by deep sea bottoms than Sardinia, which has therefore experienced longer and more repeated periods of biogeographical isolation.

Around 5\% (16 taxa) of the Sardinian vascular endemic flora is composed of less common taxa shared with the Tuscan Archipelago, which constituted the land-bridge connecting the Italian peninsula to Corsica and Sardinia during the Plio-Pleistocene eustatic fluctuations [102,103]. Within the Tuscan Archipelago, the island of Capraia (the closest one to Corsica) is the one that mainly shares the Hercynian intrusive substrates - and calcifuge taxa linked to them -with Sardinia and Corsica [104]. These conditions are common in several Sardinian crystalline massifs, such as Gennargentu [105], Sette Fratelli [106] or Limbara [107]. Taken together, these taxa represent the overwhelming majority of endemic vascular taxa and support the biogeographic scheme that characterises the independent Cyrno-Sardinian and Tuscan Archipelago province, already reported on the basis of faunistic and floristic approaches [e.g., 19,29,108-111].

The remaining few - but not less interesting - endemics are those shared with the Balearic Archipelago and other Hercynian linked areas (i.e., continental and small islands in present-day Provence) or eastern and southern insular and continental territories including Sicily, the Calabrian arc in southern Italy and northern African regions of Kabylia and Kroumirie. These are mainly palaeoendemic relics of the pre-Oligocene connection $[4,112,113]$, as it seems the case for Thymus herba-barona [6], Soleirolia soleirolii [114] and Arenaria balearica [115], which often followed a well-documented east-to-west colonisation route (from the Irano-Turanian to the Anatolian plate and then to the Mediterranean), as in the cases of Lamyropsis [85], Arum, Biarum and Helicodiceros [4]. Other typical examples are explained by the Messinian model, when sea regressions opened lands suitable for plant colonisation and set connections among several territories, currently separated by the Mediterranean Sea [116,117].

\subsection{Conservation status of the endemic Sardinian flora}

As regards the conservation status of the endemic vascular flora, we can look at the glass as half full or half empty. On the one hand, an important percentage of endemics $(26 \%)$ are under the IUCN Least Concern (LC) category. Some of them, such as Arum 
pictum subsp. pictum or Vinca difformis subsp. sardoa, are neither rare nor threatened. Others, such as Armeria sulcitana or Ferula arrigonii, although limited to a few territories, show intrinsic and extrinsic characteristics that allow them to be particularly resistant and/or resilient to pressures or to be adapted to live in remote habitats, often poor in competitors. On the other hand, $16 \%$ of the 340 endemics are either Endangered (EN) or Critically Endangered (CR). These taxa were found in decline, both in coastal and mountain areas, mainly due to human-induced habitat fragmentation and loss [e.g., 40,41,118]. Other reasons might be related to their intrinsic low genetic diversity, narrow ecological niches or population viability, which lead them to be less prone to adapt to any environmental stress and/or competition [e.g., 17,34,119-121]. Accordingly, several ex situ and in situ activities have been especially undertaken for those taxa currently assessed as the most endangered [e.g., 44,86,122-124].

Several taxa are still not assessed. The fact that most of them are inquirenda and/or having transnational distribution is not surprising. First, this suggests that propaedeutic taxonomical studies are needed to uncover the missing information about their conservation status. Genetic and phylogenetic studies have been underutilised for the establishment of priorities for conservation in most of the Mediterranean region [125]; delineating evolutionary entities, which must be those that will be subject to both ex situ and in situ conservation [126], is another crucial step towards better conservation of Sardinian flora. Second, further and larger collaborations among experts from different countries are necessary to define global conservation status of several unassessed taxa. In consideration of the important level of regional responsibility [127] of the Sardinian community, due to the high rate of endemic vascular plants and the amount of rare and/or threatened taxa [11], filling these important gaps is crucial to better address upcoming efforts in conservation planning and policy.

\section{Materials and Methods}

\subsection{Study area}

Sardinia and its ca. 400 satellite minor islands, with a total surface area of $24,090 \mathrm{~km}^{2}$, is the second largest Mediterranean island after the other Italian island of Sicily. Sardinian landscape is dominated by hilly lands, plateaus, and plains with several isolated groups of low mountains or massifs, the highest of which is the Gennargentu, with a maximum elevation of 1,834 $\mathrm{m}$ a.s.l. The heterogeneity of substrata is mainly evidenced by Palaeozoic limestones, metamorphites and batholiths, a sedimentary lithostratigraphic complex related to a Mesozoic marine transgression, Tertiary marine and volcanic depositions related to the opening of the Tyrrhenian Basin, and Quaternary alluvial deposits [128].

Two macrobioclimates (Mediterranean and Temperate submediterranean), four classes of continentality (from weak semihyperoceanic to weak subcontinental), eight thermotypic horizons (from lower thermomediterranean to upper supratemperate) and seven ombrothermic horizons (from lower dry to lower hyperhumid) were defined for the entire region [129-131].

Six biogeographical sectors were defined based on the distribution of the endemic plants in relation to the local geology and geomorphology [29] and according to the highly diversified vegetation with 23 dynamic series (21 exclusive of Sardinia, two shared with Corsica) and five geoseries (two exclusive of Sardinia and one shared with Corsica) [130]. These sectors where hierarchically defined within the Sardinian subprovince, the CyrnoSardinian and Tuscan Archipelago province, and the Italo-Tyrrhenian superprovince, which extends over the western coast of the Italian Peninsula, from Liguria to Calabria $[19,29]$. The island possesses highly polymorphic genera that, favoured by isolation and environmental heterogeneity, are currently or recently playing key roles in the evolution- 
ary processes of differentiation, and resulting gradual speciation of several endemic lineages, such as the so-called neoendemics belonging to the genera Limonium [57], Centaurea [88], Portulaca [132] or Aquilegia [119], among others.

\subsection{Origin and evolution of the endemic component of the Sardinian Flora}

The endemic plant composition - like most of the native flora - is shaped by the complex geologic and climatic history of Western Mediterranean Basin, that has been synthesised in three main events (Figure 3).
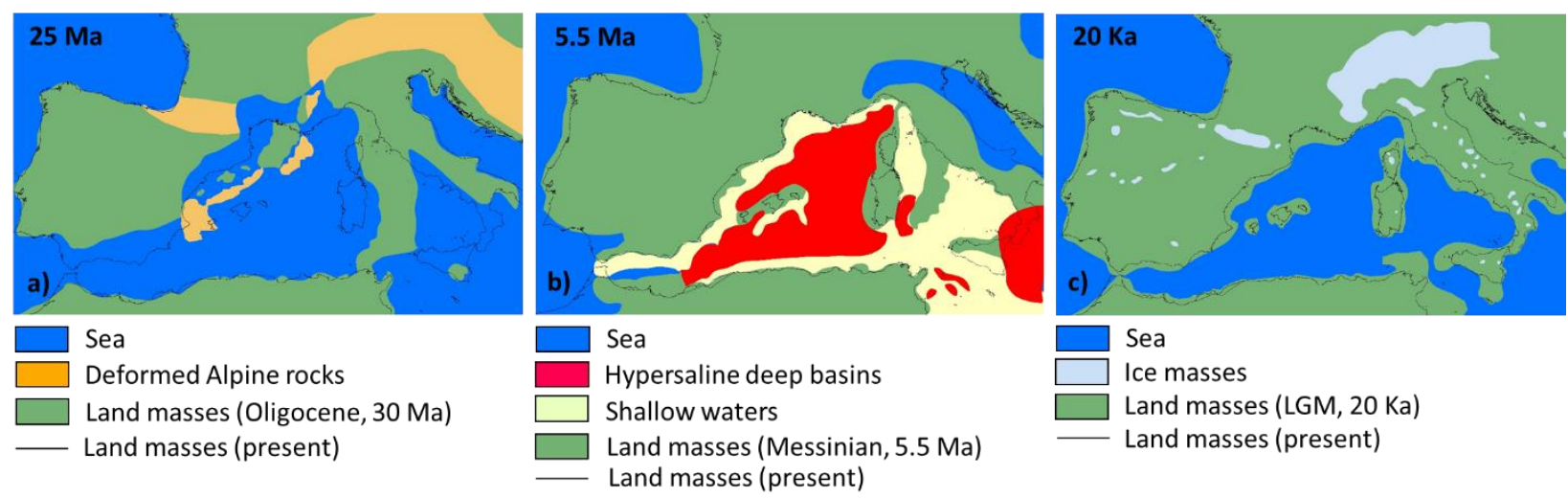

Figure 3. Palaeogeographical maps of the western Mediterranean Basin during the three main episodes that explain the current patterns of Sardinian plant distribution and their biogeographical links: a) the backward migration of the 'Hercynian islands' during the Oligocene (ca. 30-15 Ma), redrawn after [4,133]; b) the Messinian salinity crisis due to the closure of the Mediterranean-Atlantic gateways during the Late Miocene (ca. 6-5 Ma), redrawn after [28,134]; c) the climatic and eustatic changes of the Pleistocene, occurred from Early Pliocene (ca. $5 \mathrm{Ma}$ ) until the Last Glacial Maximum (LGM, ca. 20,000 years ago), redrawn after [102,103].

The oldest is the mid-Tertiary fragmentation and rotation of the eastern Balearic Archipelago, Corsica, Sardinia, interior Calabrian arch and Peloritan Massif of north-eastern part of Sicily from the current southern France and north-eastern Spain or the so-called "Protoligurian massif" [133]. The distribution of several Tyrrhenian endemic plants shared between these islands reflects this palaeogeographical event. Some examples are Arenaria balearica [115], Arum pictum, Helicodiceros muscivorus [4], Soleirolia soleirolii and Teucrium marum [28,109], or the ancestral to the vicariant species belonging to genera like Cymbalaria or Thymus [6,7]. The Messinian salinity crisis of the Late Miocene is another biogeographical event caused by the closure of the Mediterranean-Atlantic connection. This event induced an almost complete desiccation of the Mediterranean Sea and the formation of land bridges that connected, for the last time, the Cyrno-Sardinian system to the Apulian plate and the African continent [116,135,136]. During this period, some opportunities of dispersal-vicariance events and species radiations existed for drought-resistant plant species belonging to xerophytic and halophytic communities. Among the Sardinian taxa that currently show such disjunct or vicariant distributions are those of the Cephalaria squamiflora group and the Erodium subg. Barbata $[117,137]$. Furthermore, at the end of the Messinian salinity crisis, the relatively fast re-filling of the Mediterranean Basin caused the isolation of previously well connected plant populations, that underwent a typical process of allopatric speciation, often originating groups of morphologically similar, geographically vicariant endemic species (schizoendemics): a well-known model, is that of 
the Silene mollissima group, that comprises 10 to 12 narrow endemic species [81,116], including the Sardinian Silene ichnusae, and the Cyrno-Sardinian Silene velutina [121]. Last, climatic and eustatic changes during the late Pliocene and Early-Middle Pleistocene also profoundly affected the biogeographical footprint of several Mediterranean lineages and plant assemblages, allowing for the possible terrestrial migration of a more competitive cool-temperate flora onto some offshore islands that served as glacial refugia, sensu Médail \& Diadema [24]. The current distribution pattern of most of the endemic plants that are shared within the Cyrno-Sardinian and Tuscan Archipelago province, such as Borago pygmaea, Carex microcarpa or Pancratium illyricum [5,82,138,139], was influenced by this event. Like in the well-documented case of deciduous Quercus [140-142], island glacial refugia favoured the differentiation of genetic lineages of several plant groups. Some of them spread throughout the continents after the glacial ages, whereas others remained confined to the islands, giving rise to endemic taxa.

\subsection{Criteria for the selection of endemic taxa}

The main criterion to discriminate endemic from non-endemic taxa, was based on the biogeographical approach proposed by Médail \& Quézel [66], that identified the high rate of plant endemicity of the Tyrrhenian Islands macro-hotspot as a result of a series of shared palaeogeographical events. That is, we considered a taxon as a Sardinian endemic when its distribution is confined to Sardinia or to Sardinia and at least another Tyrrhenian Island. Some taxa also present in limited neighbouring and palaeogeographically related continental territories were also included.

The initial checklist was obtained from the literature on the hitherto known flora of Sardinia $[9,19,31,54]$ and neighbouring territories - mainly islands - whose endemic flora is partially shared with Sardinia [e.g., 143-147] and integrated according to more recent specific publications, mainly focused on the taxonomic description, revision and distribution of endemic taxa [e.g., 7,75,107]. Online databases, such as Euro+Med Plantbase [149], Plants of the World Online [150] or the Italian FlorItaly [151], the Spanish ANTHOS [152] or the French Inventaire National du Patrimoine Naturel - INPN [153] were also consulted. We focused on only species and subspecies levels, which were nomenclaturally updated according to Bartolucci et al. [154], and critically reviewed by the authors and acknowledged external Mediterranean experts. Distribution data were mostly gleaned from the collections compiled in the second half of the $19^{\text {th }}$ century, housed at CAG, CAT, FI, NAP, PAL, SASSA, SS, TO and CJB herbaria. Further relevant distribution data, as well as the Raunkiaer's life form of each taxon, were obtained from the above-mentioned literature and integrated by experts' unpublished knowledge. Chorological categories of the considered taxa were then defined according to their currently known distribution, following the scheme reported in Bacchetta and Pontecorvo [13] and updated in successive floras $[98,105,155,156]$.

Since the taxonomy of several taxa is still debated and/or their presence in the island is not always sure or recently confirmed, taxa were included in the final checklist as includenda (i.e., currently taxonomically valid taxa, undoubtedly present in Sardinia), inquirenda (i.e., taxa of taxonomically doubtful validity and/or whose presence in Sardinia is in need of further investigations) or excludenda (i.e., currently taxonomically invalid taxa and/or whose presence in Sardinia was reported at only one time but not recognised by further research and/or never confirmed in the field in the last 50 years). Finally, all the global conservation statuses of the includenda and inquirenda taxa were retrieved from the available literature [e.g., 32] or the IUCN database [157]. All the mentioned information is reported for each taxon in the Supplementary Materials (Tables S1, S2).

\section{Conclusions}


This checklist confirms the phylogeographic and conservation interest of the endemic vascular flora of Sardinia. It is the result of a thorough survey of regional literature, web platforms, unpublished data and expert opinions from the authors and other external acknowledged experts. The current state of the art was resumed. Nonetheless, as almost all floras, also this one is a work in progress, which must be constantly and dynamically updated. For instance, endemic species not yet known to science can be discovered in remote places, and cryptic taxa can be hidden under the disguise of morphological similarity and will be detectable with molecular methods. These knowledge gaps need to be prioritised in the research and funding institution agendas. Our dynamic approach illustrates converging, but also debatable perceptions and points of view, to enable more critical assessments and to emphasise the need of basic and advanced research on botany in Sardinia. Further efforts in conservation planning and policy might complete the optimistic aim of preserving this unreplaceable heritage for the future generations. In this sense, we underline once again the lack of a regional law for the protection of the Sardinian flora [e.g., 19,158], and the need of a more updated and inclusive international legal framework [159-162].

Supplementary Materials: The following supporting information can be downloaded at: www.mdpi.com/xxx/s1, Table S1: List of taxa includenda and inquirenda with the following information: (1) Dominant biological form, (2) Distribution, (3) Chorological category, (4) Biogeographical unit, (5) Global IUCN assessment and its sources; Table S2: List of taxa excludenda with the following information: (1) Dominant biological form; (2) Distribution (invalidated); (3) chorological category (invalidated), (4) Biogeographical unit (invalidated).

Author Contributions: Conceptualization, M.F., E.F. and G.B.; methodology, M.F., E.F., G.F. and G.B.; formal analysis, M.F.; data curation, All authors; writing-original draft preparation, M.F., E.F.; writing - review and editing, All authors; funding acquisition, E.F. and G.B. All authors have read and agreed to the published version of the manuscript.

Funding: This research received no external funding.

Data Availability Statement: All data used in this research are available in the Supplementary materials.

Acknowledgments: The authors are grateful to all the staff of the mentioned Herbaria for providing free access to all the requested material. Special mention should be made of the herbarium staff of the Conservatoire et Jardin Botaniques de la Ville de Genève (CJB), who scanned more than 100 specimens upon our request. We would also like to thank the external experts, Professors Salvatore Brullo, Angelo Troia, and Salvatore Pasta for their kind and valuable comments.

Conflicts of Interest: The authors declare no conflict of interest.

\section{References}

1. Thompson, J.D. Plant Evolution in the Mediterranean. Oxford University Press: Oxford, UK, 2005; pp. 1-304.

2. Favarger, C.; Contandriopoulos, J. Essai sur l'endémisme. Bull. Soc. Bot. Suisse 1961, 77, 383-408.

3. Contandriopoulos, J.; Favarger, C. Problémes posés par l'endémisme en Méditerranée. Colloques Internationaux du CNRS 1975, 235, 175-194.

4. Mansion, G.; Rosenbaum, G.; Schoenenberger, N.; Bacchetta, G.; Rosselló, J. A.; Conti, E. Phylogenetic analysis informed by geological history supports multiple, sequential invasions of the Mediterranean Basin by the angiosperm family Araceae. System. Biol. 2008, 57, 269-285. https://doi.org/10.1080/10635150802044029

5. Mansion, G.; Selvi, F.; Guggisberg, A.; Conti, E. Origin of Mediterranean insular endemics in the Boraginales: integrative evidence from molecular dating and ancestral area reconstruction. J. Biogeogr. 2009, 36, 1282-1296. https://doi.org/10.1111/j.13652699.2009.02082.x

6. Molins, A.; Bacchetta, G.; Rosato, M.; Rosselló, J. A.; Mayol, M. Molecular phylogeography of Thymus herba-barona (Lamiaceae): insight into the evolutionary history of the flora of the western Mediterranean islands. Taxon 2011, 60, 1295-1305. https://doi.org/10.1002/tax.605006 
7. Carnicero, P.; Schönswetter, P.; Garcia-Jacas, N.; Galbany-Casals, M. Is there a need for accepting paraphyletic taxa? A case study in the Sardinian endemic Cymbalaria muelleri (Plantaginaceae). Bot. J. Linn. Soc. 2019, 191, 325-338. https://doi.org/10.1093/botlinnean/boz052

8. López-Alvarado, J.; Mameli, G.; Farris, E.; Susanna, A.; Filigheddu, R.; Garcia-Jacas, N. Islands as a crossroad of evolutionary lineages: a case study of Centaurea sect. Centaurea (Compositae) from Sardinia (Mediterranean Basin). PloS one 2020, 15, e0228776. https://doi.org/10.1371/journal.pone.0228776

9. Arrigoni, P.V.; Camarda, I.; Corrias, B.; Diana Corrias, S.; Nardi, E.; Raffaelli, M.; Valsecchi, F. Le piante endemiche della Sardegna. Boll. Soc. Sarda. Sci. Nat. 1976-1992, 1-202.

10. Arrigoni, P. V. Le piante endemiche della Sardegna. Introduzione. Boll. Soc. Sarda. Sci. Nat. 1976, 16, $259-264$.

11. Bacchetta, G.; Farris, E.; Pontecorvo, C. A new method to set conservation priorities in biodiversity hotspots. Plant Biosyst. 2012, $146,638-648$.

12. Thompson, J.D. Plant Evolution in the Mediterranean, Insights for Conservation, 2nd ed. Oxford University Press: Oxford, 2020, pp. 1-352. https://doi.org/10.1093/oso/9780198835141.001.0001

13. Bacchetta, G.; Pontecorvo, C. Contribution to the knowledge of the endemic vascular flora of Iglesiente (SW Sardinia-Italy). Candollea 2005, 60, 481-501.

14. Nikolić, T.; Antonić, O.; Alegro, A.L.; Dobrović, I.; Bogdanović, S.; Liber, Z.; Rešetnik, I. Plant species diversity of Adriatic islands: An introductory survey. Plant Biosyst. 2008, 142, 435-445. https://doi.org/10.1080/11263500802410769

15. Jeanmonod, D. Révision de la section Siphonomorpha Otth du genre Silene, L. en Méditerranée occidentale. II: Le Group Du Silene mollissima. Candollea 1984, 39, 195-259.

16. Bacchetta, G.; Coppi, A.; Pontecorvo, C.; Selvi, F. Systematics, phylogenetic relationships and conservation of the taxa of Anchusa (Boraginaceae) endemic to Sardinia (Italy). Syst. Biodivers. 2008, 6, 161-174. https://doi.org/10.1017/S1477200008002673

17. Gentili, R.; Fenu, G.; Mattana, E.; Citterio, S.; De Mattia, F.; Bacchetta, G. Conservation genetics of two island endemic Ribes spp. (Grossulariaceae) of Sardinia: survival or extinction? Plant Biol. 2015, 17, 1085-1094. https://doi.org/10.1111/plb.12330

18. Laffan, S. W.; Crisp, M. D. Assessing endemism at multiple spatial scales, with an example from the Australian vascular flora. J. Biogeogr. 2003, 30, 511-520. https://doi.org/10.1046/j.1365-2699.2003.00875.x

19. Bacchetta, G.; Fenu, G.; Mattana, E. A checklist of the exclusive vascular flora of Sardinia with priority rankings for conservation. An. Jard. Bot. Madr. 2012, 69, 81-89. https://doi.org/10.3989/ajbm.2289

20. Peruzzi, L.; Conti, F.; Bartolucci, F. An inventory of vascular plants endemic to Italy. Phytotaxa $2014,168,1-75$. https://doi.org/10.11646/phytotaxa.168.1.1

21. Farris, E.; Carta, M.; Circosta, S.; Falchi, S.; Papuga, G.; de Lange P. The indigenous vascular flora of the forest domain of Anela (Sardinia, Italy). Phytokeys 2018, 113, 97-143. https://doi.org/10.3897/phytokeys.113.28681

22. Hobohm, C. Endemism in Vascular Plants. Springer press: Netherlands, 2014; pp. 1-348. https://doi.org/10.1007/978-94-007-6913-7

23. Cañadas, E. M.; Fenu, G.; Peñas, J.; Lorite, J.; Mattana, E.; Bacchetta, G. Hotspots within hotspots: Endemic plant richness, environmental drivers, and implications for conservation. Biol. Conserv. 2014, 170, 282-291. https://doi.org/10.1016/j.biocon.2013.12.007

24. Médail, F.; Diadema, K. Glacial refugia influence plant diversity patterns in the Mediterranean Basin. J. Biogeogr. 2009, 36, 13331345. https://doi.org/10.1111/j.1365-2699.2008.02051.x

25. Fineschi, S.; Cozzolino, S.; Migliaccio, M.; Musacchio, A.; Innocenti, M.; Vendramin, G. G. Sicily represents the Italian reservoir of chloroplast DNA diversity of Quercus ilex L. (Fagaceae). Ann. For. Sci. 2005, 62, 79-84. https://doi.org/10.1051/forest:2004085

26. Agrimonti, C.; Bianchi, R.; Bianchi, A.; Ballero, M.; Poli, F.; Marmiroli, N. Understanding biological conservation strategies: a molecular-genetic approach to the case of myrtle (Myrtus communis L.) in two Italian regions: Sardinia and Calabria. Conserv. Genet. 2007, 8, 385-396. https://doi.org/10.1007/s10592-006-9177-y

27. Fernández-Mazuecos, M.; Jiménez-Mejías, P.; Rotllan-Puig, X.; Vargas, P. Narrow endemics to Mediterranean islands: moderate genetic diversity but narrow climatic niche of the ancient, critically endangered Naufraga (Apiaceae). Perspect. Plant Ecol. Evol. 2014, 16, 190-202. https://doi.org/10.1016/j.ppees.2014.05.003

28. Médail, F. Plant biogeography and vegetation patterns of the Mediterranean islands. Bot. Rev. 2021, 1-67. https://doi.org/10.1007/s12229-021-09245-3

29. Fenu, G.; Fois, M.; Cañadas, E. M.; Bacchetta, G. Using endemic-plant distribution, geology and geomorphology in biogeography: the case of Sardinia (Mediterranean Basin). System. Biodivers. 2014, 12, 181-193. https://doi.org/10.1080/14772000.2014.894592

30. Fois, M.; Fenu, G.; Cañadas, E. M.; Bacchetta, G. Disentangling the influence of environmental and anthropogenic factors on the distribution of endemic vascular plants in Sardinia. PloS one 2017, 12, e0182539. https://doi.org/10.1371/journal.pone.0182539

31. Bacchetta, G.; Iiriti, G.; Pontecorvo, C. Contributo alla conoscenza della flora vascolare endemica della Sardegna. Inform. Bot. Ital. 2005, 37, 306-307.

32. Orsenigo, S.; Montagnani, C.; Fenu, G.; Gargano, D.; Peruzzi, L.; Abeli, T.; Alessandrini, A.; Bacchetta, G.; Bartolucci, F.; Bovio, M.; et al. Red Listing plants under full national responsibility: Extinction risk and threats in the vascular flora endemic to Italy. Biol. Conserv. 2018, 224, 213-222. https://doi.org/10.1016/j.biocon.2018.05.030

33. Orsenigo, S.; Fenu, G.; Gargano, D.; Montagnani, C.; Abeli, T.; Alessandrini, A., Bacchetta, G.; Bartolucci, F.; Carta, A.; Castello, $\mathrm{M}$; et al. Red list of threatened vascular plants in Italy. Plant Biosyst. 2021, 155, $310-335$. https://doi.org/10.1080/11263504.2020.1739165 
34. Budroni, M. A.; Farris, E.; Zirulia, A.; Pisanu, S.; Filigheddu, R.; Rustici, M. Evidence for age-structured depensation effect in fragmented plant populations: The case of the Mediterranean endemic Anchusa sardoa (Boraginaceae). Ecol. Complex. 2014, 20, 142-150. https://doi.org/10.1016/j.ecocom.2014.09.007

35. Bacchetta, G.; Fenu, G.; Mattana, E.; Pontecorvo, C. Ecological remarks on Astragalus maritimus and A. verrucosus, two threatened exclusive endemic species of Sardinia. Acta Bot. Gall. 2011, 158, 79-91. https://doi.org/10.1080/12538078.2011.10516256

36. Pisanu, S.; Farris, E.; Filigheddu, R.; García, M. B. Demographic effects of large, introduced herbivores on a long-lived endemic plant. Plant Ecol. 2012, 213, 1543-1553. https://doi.org/10.1007/s11258-012-0110-9

37. Farris, E.; Filigheddu, R.; Mameli, G.; Falanga, V.; Vanetti, I.; Rosati, L.; Binelli, G. Is population genetic structure of vascular plants shaped more by ecological or geographic factors? A study case on the Mediterranean endemic Centaurea filiformis (Asteraceae). Plant Biol. 2018, 20, 936-947. https://doi.org/10.1111/plb.12853

38. Bagella, S.; Caria, M. C.; Farris, E.; Filigheddu, R. Spatial-time variability and conservation relevance of plant communities in Mediterranean temporary wet habitats: A case study in Sardinia (Italy). Plant Biosyst. 2009, 143, 435-442. https://doi.org/10.1080/11263500903187068

39. Farris, E.; Rosati, L.; Secchi, Z.; Filigheddu, R. Are all pastures eligible for conservation? A phytosociological survey of the Sardinian-Corsican province as a basic tool for the Habitats Directive. Plant Biosyst. 2013, 147, 931-946. https://dx.doi.org/10.1080/11263504.2013.778911

40. Fenu, G.; Cogoni, D.; Ulian, T.; Bacchetta, G. The impact of human trampling on a threatened coastal Mediterranean plant: The case of Anchusa littorea Moris (Boraginaceae). Flora 2013, 208, 104-110. https://doi.org/10.1016/j.flora.2013.02.003

41. Farris, E.; Pisanu, S.; Ceccherelli, G.; Filigheddu, R. Human trampling effects on Mediterranean coastal dune plants. Plant Biosyst. 2013, 147, 1043-1051. https://doi.org/10.1080/11263504.2013.861540

42. Fois, M.; Fenu, G.; Bacchetta, G. Global analyses underrate part of the story: finding applicable results for the conservation planning of small Sardinian islets' flora. Biodivers. Conserv. 2016, 25, 1091-1106. https://doi.org/10.1007/s10531-016-1110-1

43. Fois, M.; Podda, L.; Médail, F.; Bacchetta, G. Endemic and alien vascular plant diversity in the small Mediterranean islands of Sardinia: Drivers and implications for their conservation. Biol. Conserv. 2020, 244, 108519. https://doi.org/10.1016/j.biocon.2020.108519

44. Fenu, G.; Fois, M.; Cogoni, D.; Porceddu, M.; Pinna, M. S.; Lombraña, A. C., Nebot, A.; Sulis, E.; Picciau, R.; Santo, A.; et al. The Aichi Biodiversity Target 12 at regional level: an achievable goal? Biodivers. 2015, 16, 120-135. https://doi.org/10.1080/14888386.2015.1062423

45. Pasta, S.; Perez-Graber, A.; Fazan, L.; de Montmollin, B. The Top 50 Mediterranean Island Plants UPDATE 2017. IUCN/SSC/Mediterranean Plant Specialist Group: Neuchâtel, Switzerland, 2017; pp. 1-141. Available online: https://top50.iucn-mpsg.org/book (accessed on 20 April 2021)

46. Allioni, C. Fasciculus stirpium Sardiniae in Diocesi Calari lectarum a M.A. Plazza, Chirurgo taurinensi, quos in usum botanicorum recenset. C.A. Misc. Phil.-math. Soc. Priv. Taurinensis 1759, 1, 88-103.

47. Moris, G.G. Flora Sardoa, Vol. 1-3. Ex Regio Typographeo: Taurini, 1837-1859.

48. Barbey, W. Florae Sardoae Compendium. Georges Bridel Editeur, Lausanne, 1884.

49. Martelli, U. Monocotyledones Sardoae, 1-2. Tip. Niccolai: Firenze, 1896.

50. Martelli, U. Monocotyledones Sardoae, 3. Stab. Tip. Cappelli: Rocca S. Casciano, 1904.

51. Terracciano, A. La Flora Sardoa di M.A. Plazza da Villafranca redatta coi suoi manoscritti. Memoria Reale Acc. Sc. Torino 1914, 64, 154.

52. Terracciano, A. La Flora Sardoa di M.A. Plazza da Villafranca redatta coi suoi manoscritti. Memoria Reale Acc. Sc. Torino 1914, 65, 153.

53. Terracciano, A. La Flora Sardoa di M.A. Plazza da Villafranca redatta coi suoi manoscritti. Memoria Reale Acc. Sc. Torino 1930, 67, 178.

54. Arrigoni, P. V. Flora dell'Isola di Sardegna [Flora of the island of Sardinia], Vols. 1-6. Delfino: Sassari, $2006-2015$.

55. Viciani, D.; Ferretti, G.; Bernardini, A.; Raffaelli, M.; Lastrucci, L. An annotated checklist of the vascular flora of the Arezzo administrative province (Tuscany, Italy). Plant Biosyst. 2020, 155, 971-982. https://doi.org/10.1080/11263504.2020.1810811

56. Beierkuhnlein, C.; Walentowitz, A.; Welss, W. FloCan-A Revised Checklist for the Flora of the Canary Islands. Diversity 2021, 13, 480. https://doi.org/10.3390/d13100480

57. Arrigoni, P. V.; Diana, S. Karyology, chorology and bioecology of the genus Limonium (Plumbaginaceae) in Sardinia. Plant Biosyst. 1999, 133, 63-71. https://doi.org/10.1080/11263509909381533

58. Bacchetta, G.; Brullo, S.; Terrasi, M. C. A new species of Hypochaeris L. (Asteraceae, Cichorieae) from Sardinia. Willdenowia 2003, 33, 71-78. https://doi.org/10.1080/14888386.2015.1062423

59. Lussu, M.; Marignani, M.; Lai, R.; Loi, M. C.; Cogoni, A.; Cortis, P. A Synopsis of Sardinian Studies: Why Is it Important to Work on Island Orchids? Plants 2020, 9, 853. https://doi.org/10.3390/plants9070853

60. Duminil, J.; Di Michele, M. Plant species delimitation: a comparison of morphological and molecular markers. Plant Biosyst. 2009, 143, 528-542. https://doi.org/10.1080/11263500902722964 
61. Romeiras, M. M.; Carine, M.; Duarte, M. C.; Catarino, S.; Dias, F. S.; Borda-de-Água, L. Bayesian methods to analyze historical collections in time and space: a case study using Cabo Verde Endemic Flora. Front. Plant Sci. 2020, 11, 278. https://doi.org/10.3389/fpls.2020.00278

62. Vicente, A.; Alonso, M. Á.; Crespo, M. B. Born in the Mediterranean: Comprehensive Taxonomic Revision of Biscutella ser. Biscutella (Brassicaceae) based on Morphological and Phylogenetic Data1, 2. Ann. Missouri Bot. Gard. 2020, $105,195-231$. https://doi.org/10.3417/2020554

63. Médail, F. The specific vulnerability of plant biodiversity and vegetation on Mediterranean islands in the face of global change. Reg. Environ. Change 2017, 17, 1775-1790. https://doi.org/10.1007/s10113-017-1123-7

64. Zhu, H. Biogeographical evidences help revealing the origin of Hainan Island. PLoS one 2016, 11, e0151941. https://doi.org/10.1371/journal.pone.0151941

65. Meyer, J.-Y. Threat of invasive alien plants to native flora and forest vegetation of Eastern Polynesia. Pacific Sci. 2004, 58, 357-375. https://doi.org/10.1353/psc.2004.0032

66. Médail, F.; Quezel, P. Hot-spots analysis for conservation of plant biodiversity in the Mediterranean Basin. Ann Missouri Bot. Gard. 1997, 84, 112-127. https://doi.org/10.2307/2399957

67. Médail, F.; Quezel, P. Biodiversity Hot-spots in the Mediterranean Basin: setting global conservation priorities. Conserv. Biol. 1999, 13, 1510-1513. https://doi.org/10.1046/j.1523-1739.1999.98467.x

68. Brullo, C.; Brullo, S.; Giusso del Galdo, G. Considerations on the endemic flora of Sicily. In Proceedings of the Second Botanical Conference in Menorca "Islands and Plants: preservation and understanding of flora on Mediterranean islands; Cardona Pons E., Estaun Clarisó I., Comas Casademont M., Fraga i Arguimbau, P. (Eds.), 2013; pp. 177-199.

69. Sáez, L.; Fraga, P.; López-Alvarado, J. The flora of the Balearic Islands. In Proceedings of the Second Botanical Conference in Menorca "Islands and Plants: preservation and understanding of flora on Mediterranean islands; Cardona Pons E., Estaun Clarisó I., Comas Casademont M., Fraga i Arguimbau, P. (Eds.), 2013; pp. 91-103.

70. Jeanmonod, D.; Naciri, Y.; Schlüssel, A.; Gamisans, J. Floristic analyses of the Corsican flora: biogeographical origin and endemism. Candollea 2015, 70, 21-41. https://doi.org/10.15553/c2015v701a3

71. Cho, M.-S.; Yang, J.Y.; Yang, T.-J.; Kim, S.-C. Evolutionary comparison of the chloroplast genome in the woody Sonchus alliance (Asteraceae) on the Canary Islands. Genes 2019, 10, 217. https://doi.org/10.3390/genes10030217

72. Dolcher, T.; Pignatti, S. Un'ipotesi sull'evoluzione dei Limonium del bacino del Mediterraneo. Plant Biosyst. 1971, $105,95-107$. https://doi.org/10.1080/11263507109429314

73. Koutroumpa, K.; Warren, B. H.; Theodoridis, S.; Coiro, M.; Romeiras, M. M.; Jiménez, A.; Conti, E. Geo-climatic changes and apomixis as major drivers of diversification in the Mediterranean sea lavenders (Limonium Mill.). Front. Plant Sci. $2021,11,2127$. https://doi.org/10.3389/fpls.2020.612258

74. Bacchetta, G.; Brullo, S.; Velari, T. C.; Chiapella, L. F.; Kosovel, V. Analysis of the Genista ephedroides group (Fabaceae) based on karyological, molecular and morphological data. Caryologia 2012, 65, 47-61. https://doi.org/10.1080/00087114.2012.678088

75. Bacchetta, G.; Brullo, S.; Chiapella, L. F.; Velari, T. C.; Fenu, G.; Del Galdo, G. G. Taxonomic remarks on Genista salzmannii group (Fabaceae) in Sardinia and Corsica. Phytotaxa 2020, 449, 31-51. https://doi.org/10.11646/phytotaxa.449.1.4

76. Bacchetta, G.; Brullo, S.; Casti, M.; Giusso del Galdo, G. P. Taxonomic revision of the Dianthus sylvestris group (Caryophyllaceae) in central-southern Italy, Sicily and Sardinia. Nord. J. Bot. 2010, 28, 137-173. https://doi.org/10.1111/j.1756-1051.2009.00459.x

77. Terlević, A.; Rešetnik, I. Inventory of the historical Dianthus sylvestris herbarium materials from Herbarium Croaticum and Herbarium Ivo and Marija Horvat. Glasnik Hrvatskog botaničkog društva 2020, 8, 8-14. https://doi.org/10.46232/glashbod.8.1.2

78. Nebot, A.; Cogoni, D., Fenu, G.; Bacchetta, G. Breeding system and inbreeding depression in a translocated population of the endangered plant Dianthus morisianus (Caryophyllaceae). Flora 2020, 262, 151488. https://doi.org/10.1016/j.flora.2019.151488

79. Valente, L. M.; Savolainen, V.; Vargas, P. Unparalleled rates of species diversification in Europe. Proc. Royal Soc. B 2010, 277, 14891496. https://doi.org/10.1098/rspb.2009.2163

80. Naciri, Y.; Du Pasquier, P. E.; Lundberg, M.; Jeanmonod, D.; Oxelman, B. A phylogenetic circumscription of Silene sect. Siphonomorpha (Caryophyllaceae) in the Mediterranean Basin. Taxon 2017, 66, 91-108. https://doi.org/10.12705/661.5

81. Murru, V.; Grillo, O.; Santo, A.; Ucchesu, M.; Piazza, C.; Gaio, A.; Carta, A.; Bacchetta, G. Seed morpho-colorimetric analysis on some Tyrrhenian species of the Silene mollissima aggregate (Caryophyllaceae). Flora 2019, $258,151445$. https://doi.org/10.1016/j.flora.2019.151445

82. Selvi, F.; Coppi, A.; Bigazzi, M. Karyotype variation, evolution and phylogeny in Borago (Boraginaceae), with emphasis on subgenus Buglossites in the Corso-Sardinian system. Ann. Bot. 2006, 98, 857-868. https://doi.org/10.1093/aob/mcl167

83. Farris, E.; Orrù, M.; Ucchesu, M.; Amadori A.; Porceddu M.; Bacchetta, G. Morpho-colorimetric characterization of the Sardinian endemic taxa of the genus Anchusa L. by seed image analysis. Plants 2020, 9, 1321. https://doi.org/10.3390/plants9101321

84. Callmander, M.W., Phillipson, P. B.; Schatz, G. E.; Andriambololonera, S.; Rabarimanarivo, M.; Rakotonirina, N.; Raharimampionona, J.; Chatelain, C.; Gautier, L.; Lowry, P. P. The endemic and non-endemic vascular flora of Madagascar updated. Plant Ecol. Evol. 2011, 144, 121-125. https://doi.org/10.5091/plecevo.2011.513

85. Gentili, R.; Fenu, G.; Labra, M.; Bruni, I.; Mattana, E.; Bacchetta, G. Lamyropsis genus in the Mediterranean area: phylogenetic position of L. microcephala (Asteraceae: Cardueae). Plant Biosyst. 2015, 149, 944-948. https://doi.org/10.1080/11263504.2014.983204 
86. Gentili, R.; Fenu, G.; Porceddu, M.; Bruni, I.; Citterio, S.; Bacchetta, G. Genetic variability of the first-generation of Ribes sardoum, a threatened relic plant requiring translocation measures. Plant Biosyst. 2019, 153, 1-4. https://doi.org/10.1080/11263504.2018.1435574

87. Bocchieri, E., Iiriti, G. Biodiversità vegetale in sistemi microinsulari della Sicilia e della Sardegna. Biogeographia 2011, 30, 177-196. https://doi.org/10.21426/B630110594

88. Pisanu, S.; Mameli, G., Farris, E.; Binelli, G.; Filigheddu, R. A natural homoploid hybrid between Centaurea horrida and Centaurea filiformis (Asteraceae) as revealed by morphological and genetic traits. Folia Geobot. 2011, 46, 69-86. https://doi.org/10.1007/s12224010-9085-2

89. Pignatti, S. Plant geographical and morphological evidences in the evolution of the mediterranean flora (with particular reference to the Italian representatives). Webbia 1979, 34, 243-255. https://doi.org/10.1080/00837792.1979.10670170

90. Sciandrello, S.; Guarino, R.; Minissale, P.; Spampinato, G. The endemic vascular flora of Peloritani Mountains (NE Sicily): plant functional traits and phytogeographical relationships in the most isolated and fragmentary micro-plate of the Alpine orogeny. Plant Biosyst. 2015, 149, 838-854. https://doi.org/10.1080/11263504.2014.908978

91. De Castro, O.; Brullo, S.; Colombo, P.; Jury, S., De Luca, P.; Di Maio, A. Phylogenetic and biogeographical inferences for Pancratium (Amaryllidaceae), with an emphasis on the Mediterranean species based on plastid sequence data. Bot. J. Linn. Soc. 2012, 170, 12-28. https://doi.org/10.1111/j.1095-8339.2012.01268.x

92. Meloni, M.; Dettori, C. A.; Reid, A.; Bacchetta, G.; Hugot, L.; Conti, E. High genetic diversity and presence of genetic structure characterise the endemics Ruta corsica and Ruta lamarmorae (Rutaceae). Caryologia 2020, 73, 11-26. https://doi.org/10.13128/caryologia-510

93. Conti, F.; Bartolucci, F.; Bacchetta, G.; Pennesi, R.; Lakušić, D.; Niketić, M. A taxonomic revision of the Siler montanum group (Apiaceae) in Italy and the Balkan Peninsula. Willdenowia 2021, 51, 321-347. https://doi.org/10.3372/wi.51.51301

94. Bocchieri, E.; Satta, V. Flora and vegetal landscape on the island of Figarolo (NE Sardinia). Lagascalia 1999, 21, 17-46.

95. Maccioni, A.; Canopoli, L.; Cubeddu, V.; Cucca, E.; Dessena, S.; Morittu, S., Filigheddu, R.; Padedda, B. M.; Farris, E. Gradients of salinity and plant community richness and diversity in two different Mediterranean coastal ecosystems in NW Sardinia. Biodivers. Data J. 2021, 9, e71247. https://doi.org/10.3897/BDJ.9.e71247

96. Podda, L.; Meloni, F.; Fenu, G.; Iiriti, G.; Bacchetta, G. The vascular flora of the Marine Protected Area of "Capo Carbonara" (SESardinia). Fl. Medit. 2021, 31, 415-449. https://doi.org/10.7320/FlMedit31SI.415

97. Fois, M.; Fenu, G.; Bacchetta, G. Identifying and assessing the efficiency of different networks of a fine-scale hierarchy of biodiversity hotspots. Plant Ecol. Divers. 2018, 11, 121-132. https://doi.org/10.1080/17550874.2018.1474281

98. Fenu, G., Mattana, E.; Congiu, A.; Bacchetta, G. The endemic vascular flora of Supramontes (Sardinia), a priority plant conservation area. Candollea 2010, 65, 347-358. https://doi.org/10.15553/c2010v652a10

99. Camarda, I.; Brundu, G.; Carta, L.; Vacca, G.; Brunu, A. Plants and grazing: an evaluation of the effects on Sardinian endemic plants conservation. Flora Medit. 2015, 25, 263-275. https://doi.org/10.7320/FIMedit25SI.263

100. Fenu G.; Cogoni D.; Navarro F.; Concas E.; Bacchetta G. The importance of the Cisto-Lavanduletalia coastal habitat on population persistence of the narrow endemic Dianthus morisianus (Caryophyllaceae). Plant Species Biol. 2017, 32, 156-168. https://doi.org/10.1111/1442-1984.12138

101. Bagella, S.; Filigheddu, R.; Benesperi, R.; Giordani, P.; Minuto, L.; Viciani, D.; Caria M. C.; Pisanu, S.; Casazza, G. Thorn, spine and prickle patterns in the Italian flora. Plant Biosyst. 2019, 153, 118-133. https://doi.org/10.1080/11263504.2018.1474961

102. Adamson, K. R.; Hughes, P. D.; Woodward, J. C. Pleistocene glaciation of the Mediterranean mountains. Quat. Newsl. 2013, 131, 2-15.

103. Mazza, P. P.; Lovari, S.; Masini, F.; Masseti, M.; Rustioni, M. A multidisciplinary approach to the analysis of multifactorial land mammal colonization of islands. BioSci. 2013, 63, 939-951. https://doi.org/10.1525/bio.2013.63.12.7

104. Carta, A.; Bedini, G.; Guidi, T.; Foggi, B. Tuscan Archipelago flora: from genesis to conservation. In Proceedings of the Second Botanical Conference in Menorca "Islands and Plants: preservation and understanding of flora on Mediterranean islands Cardona Pons, E., Estaun Clarisó, I., Comas Casademont, M., Fraga i Arguimbau, P. (eds.), 2013; pp. 157-166.

105. Bacchetta, G.; Fenu, G.; Guarino, R.; Mandis, G.; Mattana, E.; Nieddu, G.; Scudu, C. Floristic traits and biogeographic characterization of the Gennargentu massif (Sardinia). Candollea 2013, 68, 209-220. https://doi.org/10.15553/c2012v682a4

106. Bacchetta, G.; Iiriti, G.; Mossa L. La flora endemica del Sarrabus-Gerrei: un patrimonio da tutelare e gestire. In Analisi e sistemi di gestione del territorio (Sarrabus- Gerrei) D. Artizzu (ed.), 2005; pp. 105-112.

107. Calvia, G.; Ruggero, A. The vascular flora of Mount Limbara (northern Sardinia): from a troubled past towards an uncertain future. Fl. Medit. 2020, 30, 293-313 https://doi.org/10.7320/FlMedit30.293

108. Arrigoni, P. V. Rapporti floristici tra l'Arcipelago Toscano e le terre vicine. Lav. Soc. Ital. Biogeogr. 1975, 5, 55-65. https://doi.org/10.21426/B65110064

109. Arrigoni, P. V. Aspetti corologici della flora sarda. Biogeographia 1983, 8, 65. https://doi.org/10.21426/B68110118

110. Dapporto, L.; Palagi, E.; Turillazzi, S. Cuticular Hydrocarbons of Polistes dominulus as a Biogeographic Tool: A Study of Populations from the Tuscan Archipelago and Surrounding Areas. J. Chem. Ecol. 2004, 30, $2139-2151$. https://doi.org/10.1023/B:JOEC.0000048779.47821.38 
111. Schmitt, T.; Fritz, U.; Delfino, M.; Ulrich, W.; Habel, J. C. Biogeography of Italy revisited: genetic lineages confirm major phylogeographic patterns and a pre-Pleistocene origin of its biota. Front. Zool. 2021, 18, 1-13. https://doi.org/10.1186/s12983-021-004189

112. Contandriopoulos, J. Recherches sur la flore endémique de la Corse et sur ses origines. Ann. Fac. Sci. Marseille 1962, $32,1-354$.

113. Médail, F.; Verlaque, R. Ecological characteristics and rarity of endemic plants from southeast France and Corsica: implications for biodiversity conservation. Biol. Conserv. 1997, 80, 269-281. https://doi.org/10.1016/S0006-3207(96)00055-9

114. Hamel, T.; Boulemtafes, A. Decouverte d'une endemique tyrrhenienne Soleirolia soleirolii (Urticaceae) en Algerie (Afrique du Nord). Fl. Medit. 2017, 27, 185-193. https://doi.org/10.7320/FlMedit27.185

115. Bobo-Pinilla, J.; de León, S. B. B.; Colomar, J. S.; Fenu, G.; Bacchetta, G.; de Giles, J. P.; Martínez-Ortega, M. M. Phylogeography of Arenaria balearica L. (Caryophyllaceae): evolutionary history of a disjunct endemic from the Western Mediterranean continental islands. PeerJ 2016, 4, e2618. https://doi.org/10.7717/peerj.2618

116. Bocquet, G. The Messinian model: a new outlook for the floristics and systematics of the Mediterranean area. Candollea 1978, 33, 269-287

117. Rosselló, J. A.; Cosín, R.; Bacchetta, G.; Brullo, S.; Mayol, M. Nuclear and chloroplast DNA variation in Cephalaria squamiflora (Dipsacaceae), a disjunct Mediterranean species. Taxon 2009, 58, 1242-1253. https://doi.org/10.1002/tax.584015

118. Fenu, G.; Mattana, E.; Bacchetta, G. Distribution, status and conservation of a Critically Endangered, extremely narrow endemic: Lamyropsis microcephala (Asteraceae) in Sardinia. Oryx 2011, 45, 180-186. https://doi.org/10.1017/S0030605310001122

119. Garrido, J. L.; Fenu, G.; Mattana, E.; Bacchetta, G. Spatial genetic structure of Aquilegia taxa endemic to the island of Sardinia. Ann. Bot. 2012, 109, 953-964. https://doi.org/10.1093/aob/mcs011

120. Cogoni, D.; Sulis, E.; Bacchetta, G.; Fenu, G. The unpredictable fate of the single population of a threatened narrow endemic Mediterranean plant. Biodivers. Conserv. 2019, 28, 1799-1813. https://doi.org/10.1007/s10531-019-01757-0

121. Murru, V.; Farris, E.; Santo, A.; Grillo, O.; Piazza, C.; Gaio, A., Bacchetta, G.; Thompson, J. D. Niche Differentiation at Multiple Spatial Scales on Large and Small Mediterranean Islands for the Endemic Silene velutina Pourr. ex Loisel. (Caryophyllaceae). Plants 2021, 10, 2298. https://doi.org/10.3390/plants10112298

122. Porceddu, M.; Fenu, G., Bacchetta, G. New findings on seed ecology of Ribes sardoum: can it provide a new opportunity to prevent the extinction of a threatened plant species? Syst. Biodivers. 2017, 15, 480-488. https://doi.org/10.1080/14772000.2016.1271058

123. Porceddu, M.; Santo, A., Orru, M.; Meloni, F.; Ucchesu, M.; Picciau, R., Sarigu, M.; Cuena-Lombraña, A.; Podda, L.; Sau, S.; et al. Seed conservation actions for the preservation of plant diversity: The case of the Sardinian Germplasm Bank (BG-SAR). Plant Sociol. 2017, 54, 111-117. http://dx.doi.org/10.7338/pls2017542S1/11

124. Fenu, G.; Bacchetta, G.; Christodoulou, C. S.; Cogoni, D.; Fournaraki, C.; Giusso del Galdo, G.; Gotsiou, P.; Kyratzis, A.; Piazza, C.; Vicens, M.; de Montmollin, B. A common approach to the conservation of threatened island vascular plants: First results in the Mediterranean basin. Diversity 2020, 12, 157. https://doi.org/10.3390/d12040157

125. Médail, F.; Baumel, A. Using phylogeography to define conservation priorities: The case of narrow endemic plants in the Med578 iterranean Basin hotspot. Biol. Conserv. 2018, 224, 258-266, https://doi.org/10.1016/j.biocon.2018.05.028.

126. Bobo-Pinilla J.; Salmerón-Sánchez E.; Mendoza-Fernández A.J.; Mota J.F.; Peñas J. Conservation and phylogeography of plants: from the Mediterranean to the rest of the world. Diversity 2022, 14, 78. https://doi.org/10.3390/d14020078

127. Gauthier, P.; Debussche, M.; Thompson, J. D. Regional priority setting for rare species based on a method combining three criteria. Biol. Conserv. 2010, 143, 1501-1509. https://doi.org/10.1016/j.biocon.2010.03.032

128. Carmignani, L.; Oggiano, G.; Funedda, A.; Conti, P.; Pasci, S. The geological map of Sardinia (Italy) at 1: 250,000 scale. Journal of Maps 2016, 12, 826-835. https://doi.org/10.1080/17445647.2015.1084544

129. Bacchetta, G. Flora vascolare del Sulcis (Sardegna sud-occidentale, Italia). Guineana 2006, 12, 1-369.

130. Bacchetta, G.; Bagella, S.; Biondi, E.; Farris, E.; Filigheddu, R.; Mossa, L. Vegetazione forestale e serie di vegetazione della Sardegna (con rappresentazione cartografica alla scala 1: 350.000). Fitosociologia 2009, 46, 3-82.

131. Canu, S.; Rosati, L.; Fiori, M.; Motroni, A.; Filigheddu, R.; Farris, E. Bioclimate map of Sardinia (Italy). J. Maps 2015, 11, 711718. https://doi.org/10.1080/17445647.2014.988187

132. Danin, A.; Buldrini, F.; Bandini Mazzanti, M.; Bosi, G.; Caria, M. C.; Dandria, D.; Lanfranco, E.; Mifsud, S.; Bagella, S. Diversification of Portulaca oleracea L. complex in the Italian peninsula and adjacent islands. Bot. Lett. 2016, 163, $261-272$. https://doi.org/10.1080/23818107.2016.1200482

133. Rosenbaum, G.; Lister, G. S.; Duboz, C. Reconstruction of the tectonic evolution of the western Mediterranean since the Oligocene. J Virtual Explor. 2002, 8, 107-130. https://doi.org/10.3809/jvirtex.2002.00053

134. Favre, E.; François, L.; Fluteau, F.; Cheddadi, R.; Thévenod, L.; Suc, J. P. Messinian vegetation maps of the Mediterranean region using models and interpolated pollen data. Geobios 2007, 40, 433-443. https://doi.org/10.1016/j.geobios.2006.12.002

135. Hsü, K.J.; Montadert, L.; Bernoulli, D.; Cita, M.B.; Erickson, A.; Garrison, R.E.; Kidd, R.B.; Melieres, F.; Muller, C.; Wright, R. History of Mediterranean salinity crisis. Nature 1977, 267, 399-403. https://doi.org/10.1038/267399a0

136. Cherchi, A.; Montadert L. Oligo-Miocene rift of Sardinia and the history of the Western Mediterranean Basin. Nature 1982, 298, 736-739. https://doi.org/10.1038/298736a0 
137. Fiz-Palacios, O.; Vargas, P.; Vila, R.; Papadopulos, A. S.; Aldasoro, J. J. The uneven phylogeny and biogeography of Erodium (Geraniaceae): radiations in the Mediterranean and recent recurrent intercontinental colonization. Ann. Bot. 2010, 106, 871-884. https://doi.org/10.1093/aob/mcq184

138. De Castro, O.; Innangi, M.; Di Maio, A.; Menale, B.; Bacchetta, G.; Pires, M.; Noble, V.; Gestri, G.; Conti, F.; Peruzzi, L. Disentangling phylogenetic relationships in a hotspot of diversity: the butterworts (Pinguicula L., Lentibulariaceae) endemic to Italy. PLoS one 2016, 11, e0167610. https://doi.org/10.1371/journal.pone.0167610

139. Míguez, M.; Gehrke, B.; Maguilla, E.; Jiménez-Mejías, P.; Martín-Bravo, S. (2017). Carex sect. Rhynchocystis (Cyperaceae): A Miocene subtropical relict in the Western Palaearctic showing a dispersal-derived Rand Flora pattern. J. Biogeogr. 2017, 44, 22112224. https://doi.org/10.1111/jbi.13027

140. Mossa, L.; Bacchetta, G.; Brullo, S. Quercus ichnusae (Fagaceae), a new species from Sardinia. Israel J. Plant Sci. 1999, 47, 199207. https://doi.org/10.1080/07929978.1999.10676774

141. Fineschi, S.; Taurchini, D.; Grossoni, P.; Petit, R.J.; Vendramin, G. G. Chloroplast DNA variation of white oaks in Italy. Forest Ecol. Manag. 2002, 156, 103-114. https://doi.org/10.1016/S0378-1127(01)00637-5

142. Petit, R.J., Brewer, S.; Bordács, S.; Burg, K.; Cheddadi, R.; Coart, E.; Coart, E.; Cottrell, J.; Csaikl, U. M.; van Damh, B.; et al. Identification of refugia and post-glacial colonisation routes of European white oaks based on chloroplast DNA and fossil pollen evidence. Forest Ecol. Manag 2002, 156, 49-74. https://doi.org/10.1016/S0378-1127(01)00634-X

143. Castroviejo S Flora Iberica, vols. 1-18, 21. Real Jardín Botánico-CSIC: Madrid, 1986-2019 [detailed list of volume editors and genera authors at www.foraiberica.org]

144. Giardina, G.; Raimondo, F.M.; Spadaro, V. A catalogue of plants growing in Sicily. Bocconea 2007, $20,5-582$.

145. Véla, E.; Pavon, D. The vascular flora of Algerian and Tunisian small islands: if not biodiversity hotspots, at least biodiversity hotchpotchs. Biodivers. J. 2012, 3, 343-362.

146. Jeanmonod, D.; Gamisans J. Flora Corsica. Édisud: Aix-en-Pro-vence. France, 2007.

147. Pignatti, S.; Guarino, R.; La Rosa, M. Flora d'Italia, 2nd ed.; Edagricole: Bologna, Italy, 2017-2019; Volumes 1-4.

148. Bartolucci, F.; Domina, G.; Argenti, C.; Bacchetta, G.; Ballelli, S.; Banfi, E.; Barberis, D.; Barberis, G.; Bertolli, A.; Bolpagni, R.; et al. Notulae to the Italian native vascular flora. Ital. Bot. 2021, 12, 85-103. https://doi.org/10.3897/italianbotanist.12.78038

149. Euro+Med, 2006-2020. Euro+Med PlantBase-The Information Resource for Euro-Mediterranean Plant Diversity. Available online: http://ww2.bgbm.org/EuroPlusMed/ (accessed on 16 June 2020).

150. Plants of the World Online POWO. Facilitated by the Royal Botanic Gardens, Kew. Available online: http://www.plantsoftheworldonline.org/2020 (accessed on 11 February 2021).

151. Martellos, S.; Bartolucci, F.; Conti, F.; Galasso, G.; Moro, A.; Pennesi, R.; Peruzzi, L.; Pittao, E.; Nimis, P.L. FlorItaly-The portal to the Flora of Italy. PhytoKeys 2020, 156, 55-71. https://doi.org/10.3897/phytokeys.156.54023

152. ANTHOS: Sistema de Información sobre las Plantas de España. Available online: www.programanthos.org (accessed on 21 March 2021)

153. Inventaire National du Patrimoine Naturel - INPN. Available online: https://inpn.mnhn.fr/ (accessed on 10 April 2021)

154. Bartolucci, F.; Peruzzi, L.; Galasso, G.; Albano, A.; Alessandrini, A.; Ardenghi, N.M.G.; Astuti, G.; Bacchetta, G.; Ballelli, S.; Banfi, E.; et al. An updated checklist of the vascular flora native to Italy. Plant Biosyst. 2018, 152, 179-303. https://doi.org/10.1080/11263504.2017.1419996

155. Bacchetta, G.; Casti, M.; Mossa, L. New ecological and distributive data on the rupestrian flora of Sardinia. J. Bot. Soc. Bot. France 2007, 38, 73-83.

156. Bocchieri, E.; Iiriti, G. Contribution to knowledge of the endemic vascular flora of the capes and promontories of Sardinia (Italy). Bocconea 2009; 23, 353.

157. IUCN. 2021. The IUCN Red List of Threatened Species. Version 2021-3. https://www.iucnredlist.org (accessed on 20 November 2021).

158. Rossi, G.; Montagnani, C.; Abeli, T.; Gargano, D.; Peruzzi, L.; Fenu, G.; Wagensommer, R. P.; Ravera, S.; Cogoni, A.; Aleffi, M.; et al. Are Red Lists really useful for plant conservation? The New Red List of the Italian Flora in the perspective of national conservation policies. Plant Biosyst. 2014, 148, 187-190. https://doi.org/10.1080/11263504.2013.868375

159. Fenu, G.; Bacchetta, G.; Giacanelli, V.; Gargano, D.; Montagnani, C.; Orsenigo, S.; Cogoni, D.; Rossi, G.; Conti, F.; Santangelo, A.; et al. Conserving plant diversity in Europe: outcomes, criticisms and perspectives of the Habitats Directive application in Italy. Biodivers. Conserv. 2017, 26, 309-328. https://doi.org/10.1007/s10531-016-1244-1

160. Fois, M.; Bacchetta, G.; Cogoni, D.; Fenu, G. Current and future effectiveness of the Natura 2000 network for protecting plant species in Sardinia: a nice and complex strategy in its raw state? J. Environ Plan. Manag. 2018, 61, 332-347. https://doi.org/10.1080/09640568.2017.1306496

161. Fois, M.; Bacchetta, G.; Caria, M. C.; Cogoni, D.; Farris, E., Fenu, G.; Manca, M.; Pinna, M. S.; Pisanu, S.; Rivieccio, G.; Bagella, S. Proposals for improvement of Annex I of Directive 92/43/ EEC: Sardinia. Plant Sociol. 2021, 58, 65-76. https://doi.org/10.3897/pls2021582/06

162. Cuena-Lombraña, A.; Fois, M.; Cogoni, A.; Bacchetta, G. Where we Come from and where to Go: Six Decades of Botanical Studies in the Mediterranean Wetlands, with Sardinia (Italy) as a Case Study. Wetlands 2021, 41, 69. https://doi.org/ 10.1007/s13157-021-01464-z 
